potatoes on behalf of another Danish company, Danespo, in which DLF has a 25\% stake. However, according to Gorm Palmgren, $\mathrm{R} \& \mathrm{D}$ project leader at DLF, the company has stated clearly in public that it intends to proceed with plant modification. "We are going ahead. ..We hope that things will change and that public opinion will change." DLF is less vulnerable to unjustified consumer boycotts of its products than Carlsberg or Danisco. It is the world's largest producer of clover and grass seed, supplying a third of the grass seed consumed in the European Union, and a distributor in Denmark of crops such as wheat, barley, and rapeseed.

The company is now championing the cause of the fodder beet. Prevented from planting the crop commercially, the company has conducted extensive experimental field trials during 1998 and 1999 to assess its environmental impact compared to that of conventional fodder beet. DLF conducted the trials with the Danish ministry of the environment and in consultation with environmental groups. According to two independent sources who have seen the preliminary data from those trials, they showed not only an increase in beet yield but also an increase in biological diversity, measured both by the number of weed species that emerged after the Roundup treatment ceased and the number of insects and insect species on the plots.

John Hodgson

\title{
Biotechnology becomes the new dot com
}

Three very successful initial public offerings, a surge in genomics stocks, and the biggest biotech private placement to date suggest that biotechnology is once again back in favor with investors. Analysts are optimistic that the caliber of companies today, coupled with burgeoning retail influence on the market, will sustain interest in an industry that has traditionally suffered a love-hate relationship with investors.

In December, Toolkit companies Caliper Technologies (Mountain View, CA) and Maxygen (Redwood City, CA) raised \$72 million and \$96 million in respective IPOs, while Tularik (S. San Francisco, CA), a company developing drugs that regulate gene expression, raised $\$ 97.3$ million. All offerings were oversubscribed, raised more money than planned, and have so far performed very well-by January 10, Caliper, Maxygen, and Tularik stocks were up $400 \%, 415 \%$, and $246 \%$ on their respective offer prices. At the same time, some quoted genomics companies more than tripled in value as investors poured back into the sector. Both Celera and Incyte hit alltime highs, rising $225 \%$ and $280 \%$ respectively, while Human Genome Sciences rose 55\% and Millennium Pharmaceuticals 41.2\%.

According to Eric Roberts, managing director of corporate finance at Warlburg Dillon Read (New York), interest in biotechnology is being transferred from the technology sector. "We clearly saw a rotation out of internet stocks into internet-like stocks," he says. "Investors felt that internet stocks were getting overvalued and looked for other similar sectors that have room to rise." And these companies, he explains, are the most internet-like of the biotech space because they're selling technologies for drug discovery that have very long-term payoffs.

In addition, says Steven Burrill, CEO of Burrill \& Co. (San Francisco, CA), recent sequencing news-completion of chromosome 22 and milestones in Drosophila and Arabidopsis, for example-prompted investor interest again, particularly in companies that have been able to show how their technology will tap into understanding of the human genome.

Burrill adds that another important event this year was the re-floating of parts of Genentech by Roche (Nat. Biotechnol. 17, 838). The enormously good reception by the public signaled the investment community that there was perhaps some appetite for biotechnology, he says.

Historically, however, valuations have risen too high too quickly, supply has overtaken demand, and public appetite has waned. "Investors either all want it and it's overvalued and things go up, or they all don't want it and it's undervalued and things go down," says Burrill. The biotech industry is so cyclical, he says, because there are a large number of companies (400) that are by and large undervalued (over the past 20 years, the whole industry had a market cap between about $\$ 100$ billion and $\$ 150$ billion-roughly equal to that of Pfizer at the same time); the industry is fueled by investor cash as opposed to sales and profits; and on top of that there are only a handful of analysts with very little really good hard data to analyze.

IPOs have been sparse this year, with none in the US during August, September, and October. Stelios Papadopoulis, analyst at Paine Webber (New York), explains that a protracted period of absence of IPOs allows private companies to mature so that inevitably they are better organized, better managed, better financed, etc., than they are during a very protracted IPO-friendly environment. "Clearly if this [boom] were to continue for another 6 or 9 months to a year, then you'll begin seeing some not-ready-forprime-time companies going public," he says, "It's always happened in the past."

However, he says the quality of companies is generally better these days and that firms like Tularik and Maxygen, for example, are far more solid with respect to management, strategic plan, quality of science, and the amount of finance so far available to them than the usual IPO we've seen over the past 20 years. "I believe these companies are more likely to sustain a higher valuation than some that have been swept up in excitements we've had in the past."

It's not only the public markets that are benefiting-large amounts of private capital are also going into biotech at the moment. Orchid Biocomputer (Princeton, $\mathrm{NJ}$ ), for example, raised $\$ 72$ million in January. President and CEO Dale Pfost says Orchid, a pharmacogenetics and microfluidics company, was able to raise that amount because its senior management was experienced at raising capital. "We borrowed the process that investment bankers use," he says, "Orchid's private placement memorandum resembled a prospectus for an IPO.”

Pfost says the buoyancy of the current markets is "a very good thing for us" and that Orchid is looking for an opportunity to do an IPO in the next few weeks. He says the markets will probably stay good for more than just a couple of months, but that "we never rely on those things so we need to move quickly."

Public appetite may not wane as dramatically this time as it has done in the past, however, thanks to an increase in retail investors, partly due to wider genomics coverage in the popular press. The institutional investorwhose appetite, by definition, has traditionally shut after seeing 5 or 10 IPOs-isn't really the controlling piece of the market any more, says Burrill.

In addition, the current tremendous investor interest, independent of biotechnology, could mean a more lasting interest in biotechnology. "In the broad market what we're finding is more and more people that are momentum-type investors, and as long as the momentum in particular sectors is doing well, stocks perform well," says Dennis Purcell, global head of life sciences at Chase H\&Q (San Francisco, CA). However, he adds that as investors increasingly look for huge returns, "We're going to have to learn to live with increasing volatility."

Emma Dorey 